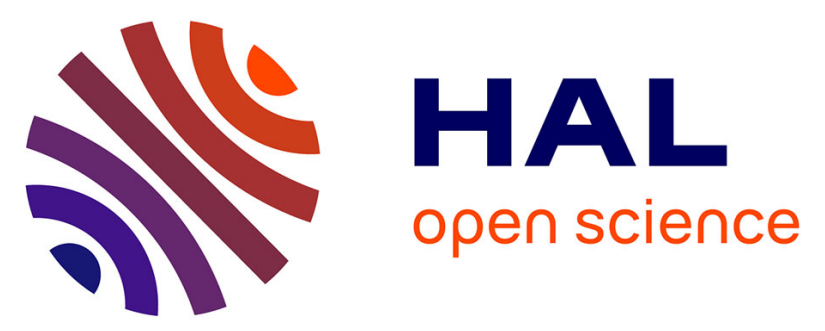

\title{
First Contributions of Charcoal Analysis to the Study of the Specialised Fishing Site of Bayovar-01 (5th-8th Centuries AD), Extreme Northern Coast of Peru
}

Nicolas Bermeo, Elliott Michelle, Nicolas Goepfert, Belkys Gutiérrez Léon, Vásquez Sánchez Segundo

\section{To cite this version:}

Nicolas Bermeo, Elliott Michelle, Nicolas Goepfert, Belkys Gutiérrez Léon, Vásquez Sánchez Segundo. First Contributions of Charcoal Analysis to the Study of the Specialised Fishing Site of Bayovar-01 (5th-8th Centuries AD), Extreme Northern Coast of Peru. Environmental Archaeology, 2021, 26 (2), pp.146-158. 10.1080/14614103.2018.1563981 . hal-02190009

\section{HAL Id: hal-02190009 \\ https://hal.science/hal-02190009}

Submitted on 2 Jan 2021

HAL is a multi-disciplinary open access archive for the deposit and dissemination of scientific research documents, whether they are published or not. The documents may come from teaching and research institutions in France or abroad, or from public or private research centers.
L'archive ouverte pluridisciplinaire HAL, est destinée au dépôt et à la diffusion de documents scientifiques de niveau recherche, publiés ou non, émanant des établissements d'enseignement et de recherche français ou étrangers, des laboratoires publics ou privés. 


\section{Environmental Archaeology}

The Journal of Human Palaeoecology

\section{First Contributions of Charcoal Analysis to the Study of the Specialised Fishing Site of Bayovar-01 (5th-8th Centuries AD), Extreme Northern Coast of Peru}

Nicolas Bermeo, Michelle Elliott, Nicolas Goepfert, Belkys Gutiérrez León \& Vásquez Sánchez Segundo

To cite this article: Nicolas Bermeo, Michelle Elliott, Nicolas Goepfert, Belkys Gutiérrez León \& Vásquez Sánchez Segundo (2019): First Contributions of Charcoal Analysis to the Study of the Specialised Fishing Site of Bayovar-01 (5th-8th Centuries AD), Extreme Northern Coast of Peru, Environmental Archaeology, DOI: 10.1080/14614103.2018.1563981

To link to this article: https://doi.org/10.1080/14614103.2018.1563981

曲 Published online: 11 Jan 2019.

Submit your article to this journal $[\pi$

山 Article views: 2

View Crossmark data \lceil 


\title{
First Contributions of Charcoal Analysis to the Study of the Specialised Fishing Site of Bayovar-01 (5th-8th Centuries AD), Extreme Northern Coast of Peru
}

\author{
Nicolas Bermeo (ib) ${ }^{\mathrm{a}, \mathrm{b}}$, Michelle Elliott $\mathbb{1}^{\mathrm{a}, \mathrm{c}}$, Nicolas Goepfert $\mathbb{1}^{\mathrm{b}}$, Belkys Gutiérrez León ${ }^{\mathrm{d}}$ and \\ Vásquez Sánchez Segundo ${ }^{\mathrm{e}}$ \\ anniversité Paris 1, Panthéon-Sorbonne Paris, France; ${ }^{\mathrm{b} C N R S-P a r i s ~ 1, ~ U M R ~} 8096$ Archéologie des Amériques Nanterre, France; ${ }^{\mathrm{C} U M R} 7041$ \\ Archéologie des Sciences de l'Antiquité Nanterre, France; ${ }^{\mathrm{d} B G L}$ Arqueología, Calle Los Pinos 518, Trujillo, Peru; ${ }^{\mathrm{e}}$ Universidad Nacional de \\ Trujillo (UNT), Ciudad Universitaria, Trujillo, Peru
}

\begin{abstract}
Recent archaeological excavations carried out at the site of Bayovar-01 (occupied from the 5th to 8th centuries $A D$ ) in the Sechura Desert provide new data on the activities and adaptations of the desert's ancient inhabitants. The presence of two small structures, a large activity area containing a significant amount of fish remains and traces of large hearths, indicate that Bayovar-01 was an opportunistic settlement, benefitting from favourable environmental conditions and serving as a specialised site for fishing and the preparation of fish. The analysis of charcoal remains from features corresponding to large hearth remains sheds light on practices of firewood gathering and usage. Taxonomic and morphological analyses reveal strong preferences for certain taxa, possible gathering strategies combining dead wood collection and tree felling, the usage of several different tree parts, and consistent combustion conditions across the processing features. Despite selection biases, taxa composition suggests the existence of different environmental conditions in the desert in the past, related to the presence of a palaeo-lagoon. Anthracological analysis thus has a potential that exceeds mere taxonomic identification of firewood, revealing gathering and usage practices, as well as insights into taxa availability that have implications for ecological and environmental variations.
\end{abstract}

ARTICLE HISTORY

Received 30 April 2018

Revised 8 December 2018

Accepted 21 December 2018

\section{KEYWORDS}

Archaeobotany;

anthracology; Sechura desert; firewood; fishing site;

smoking practices

\section{Introduction}

The Sechura desert, located on the extreme northern coast of Peru, covers $20,000 \mathrm{~km}^{2}$ and is characterised by a hyper-arid climate, with little to no precipitation almost all year round (Ferreyra 1987; Collin-Delavaud 1984). Nonetheless, archaeological surveys have recorded human settlements dating back to the 5th millennium $\mathrm{BC}$ and up to the 15th century $\mathrm{AD}$ and the dawn of the colonial period (Cardenas, Huapaya Manco, and Deza Rivasplata 1991, 1993). Recent archaeological excavations have been undertaken in this zone since 2012 by a Franco-Peruvian team as part of the 'Programme Archéologique Désert de Sechura' (Goepfert et al. 2014, 2016, forthcoming). Excavations at the site of Bayovar-01 were conducted in 2012 and 2013 with the aim of determining the function and chronology of the settlement. Located on a Pleistocene marine terrace, the site is separated from the sea by a $6 \mathrm{~km}$ wide flat depression called Las Salinas (Figure 1), where some parts are lower than sea level (Novoa Goicochea 1998). A multiproxy study carried out on this depression, including sediment and malacofauna analysis, demonstrated that it was originally a lagoon that eventually disappeared in the 8th century
$\mathrm{AD}$ due to a long process of sedimentation and the closing of the opening to the ocean by a sand bar's growth (Christol et al. 2016, 2017). It is also important to note that during times of abnormally high rainfall in the highlands and the coast, related to the ENSO phenomenon, the Sechura desert's depressions are inundated by permanent and usually dry watercourses, forming a network of temporary lakes with a combined area of more than $2000 \mathrm{~km}^{2}$ (more than $7000 \mathrm{~m}^{3}$ of water), that take years to dry out completely (Novoa Goicochea 1998).

\section{Research Questions and Objectives}

The study of charcoal remains found in large quantities at Bayovar-01 could provide insight into resource exploitation by desert inhabitants and past vegetation, particularly firewood. Anthracology has typically been applied with the aim of reconstructing past vegetation by the way of human exploitation of available firewood resources, focusing on domestic contexts of long-term use, following the principle of 'least effort' (Chabal et al. 1999; Théry-Parisot, Chabal, and Chrzavzez 2010). More recently, other aspects of charcoal analysis have 


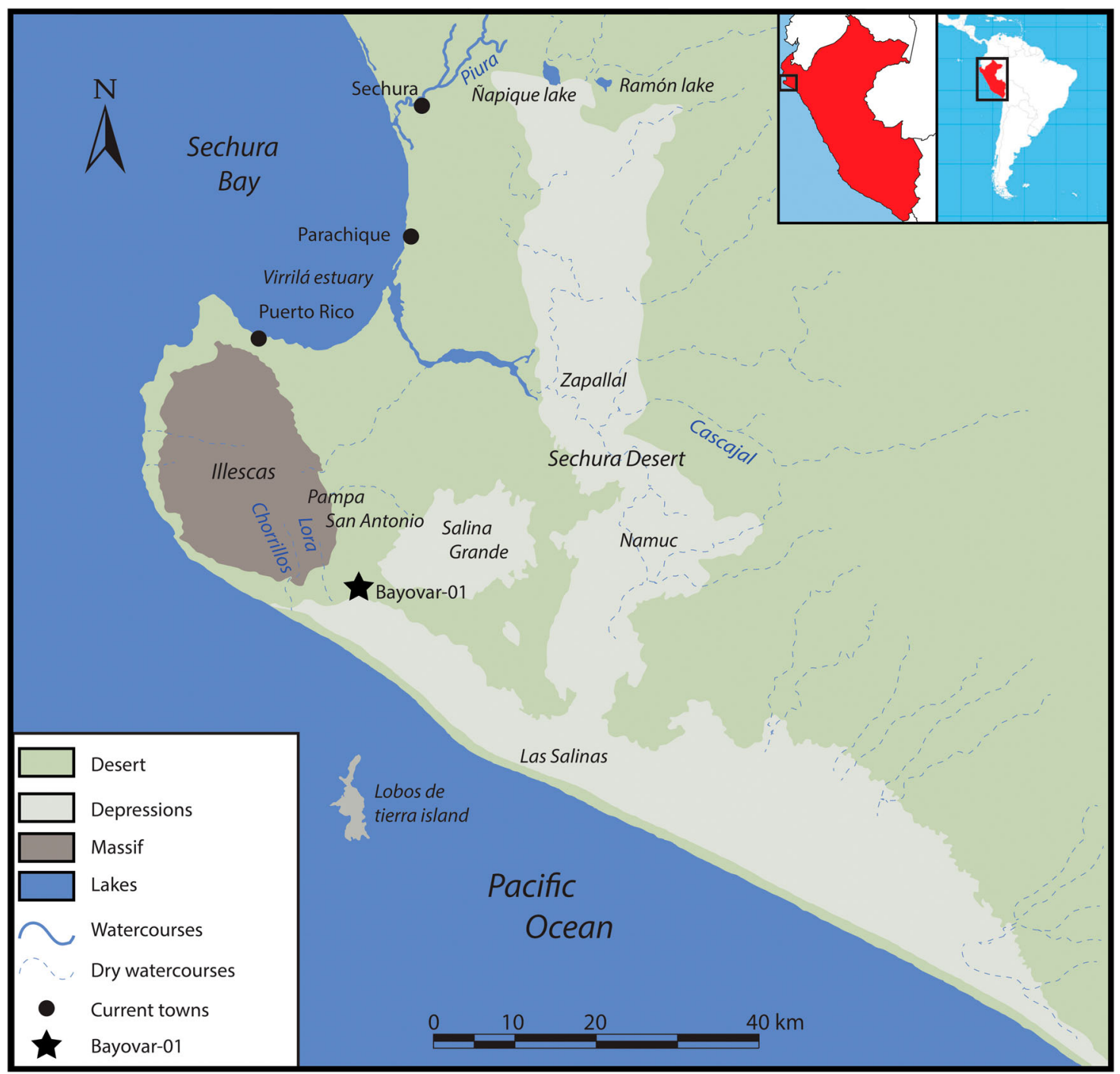

Figure 1. Location of the Sechura desert and the site of Bayovar-01. Drawn from Goepfert et al. (2016).

also been developed, with an interest for morphological and other characteristics of wood, as growth-ring measurements and curvature, cracks, vitrification, or bacterial attacks, which may provide new insights on firewood management, such as the use of dry, green, dead, drift wood, and different diameters (Marguerie and Hunot 2007; Théry-Parisot, Chabal, and Chrzavzez 2010; Caruso Fermé 2013).

Nevertheless, very few anthracological studies have been carried out in Peru: Pearsall (1980) at Pachamachay, Weir and Dering (1986) at La Paloma, Johannessen and Hastorf (1990) in the Jauja region, Moutarde (2006) in the Lurín valley and the site Huacas de Moche (2008), and Goldstein (2007; Goldstein and Shimada 2013) in La Leche valley. Moutarde (2008) and Goldstein (2007) are the only ones located in the northern coast.

The present study aims to describe the activities and practices carried out at Bayovar-01 through the lens of firewood exploitation and management in order to better understand the activities of past inhabitants of this settlement and the Sechura desert, and their relationship with their environment. The study focused on taxonomic identifications, but also considered non-taxonomic characteristics of the material. The primary goal of the study was to illustrate the potential contributions of charcoal analysis, and particularly the observation of non-taxonomic attributes, towards a better understanding of the exploitation and management of firewood resources, the fish processing practices, and the characterisation of the vegetation present around the settlement at the time of its occupation. This study not only contributes to our knowledge of the past inhabitants of the Sechura desert, their activities and relationship with their environment, as well as to past vegetation reconstruction in the area, but also to the potential of anthracological analysis to contribute to multidisciplinary research in general and beyond simple taxonomic identifications.

\section{Biogeographical and Archaeological Settings}

The site of Bayovar-01 encompasses 3 ha and is composed by two structures flanking a concentration of 
organic material where large quantities of charcoal were clearly visible (Figure 2). The excavation of the two structures revealed that they were constructed from marine formation slabs arranged in rows, some doubled with tree trunks or posts. The excavations in the organic material area consist of a $4 \mathrm{~m}^{2}$ pit $(2 \mathrm{~m} \times 2 \mathrm{~m})$, recorded as Pit 1 , and a $50 \mathrm{~m}^{2}$ area $(10 \mathrm{~m} \times 5 \mathrm{~m})$, recorded as Area 1. This sector revealed a high concentration of organic material: large quantities of fish remains, charcoal, charred seeds and camelid faeces, that were most concentrated in superposed and overlapped hearth remains of variable size, corresponding to multiple combustion activities (Figures 3 and 4). The area is interpreted as a specialised area used for processing large quantities of fish. Radiocarbon dating of material from several features place the settlement's occupation between cal. AD 489 and 766, pointing to a rather short but continuous occupation of the site (Table 1). Radiocarbon ages measured on charcoals were calibrated with the IntCal13 calibration curve, and marine shell age was calibrated using the Marine13 calibration curve (the calculation for the reservoir age is further discussed in Christol et al. 2017). The analysis of the fish remains, which included over 35,000 otoliths and more than one million other skeletal remains, shows an abundance of Mugil cephalus and Micropogonias altipinnis, as well as other fish species in minor proportions. Two taxa (Micropogonias altipinnis and Albula sp.) preferentially inhabit warm waters and today do not occur in the cold waters of the Sechura desert's coast. Nevertheless, they appear to have inhabited the warmer waters of the ancient lagoon during the site's occupation (Goepfert et al. 2016). The site of Bayovar-01 is thus thought to have been occupied by specialised fishermen who

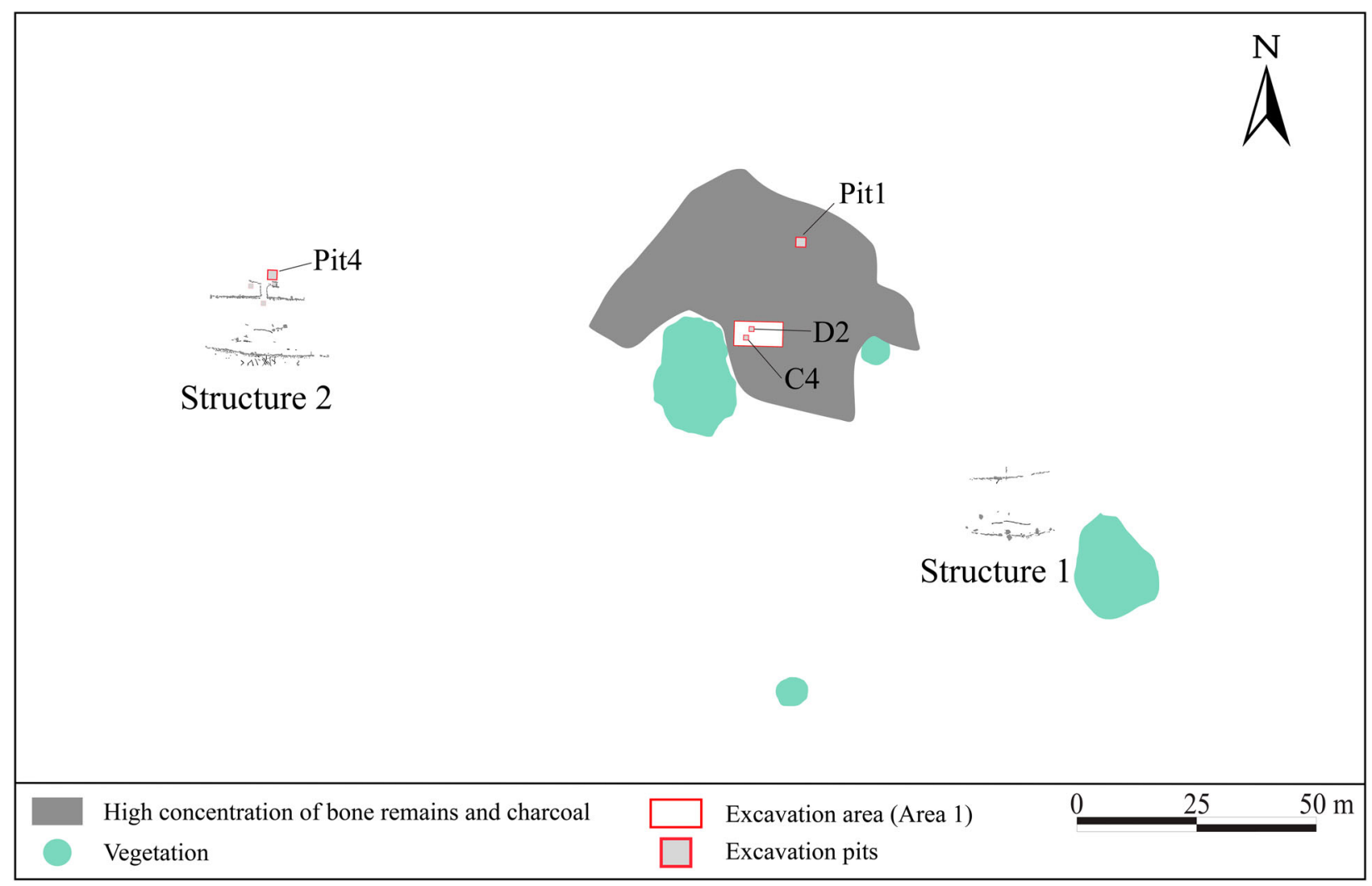

Figure 2. The site of Bayovar-01. Redrawn from H. Chiumbiauca and N. Goepfert (unpublished data).

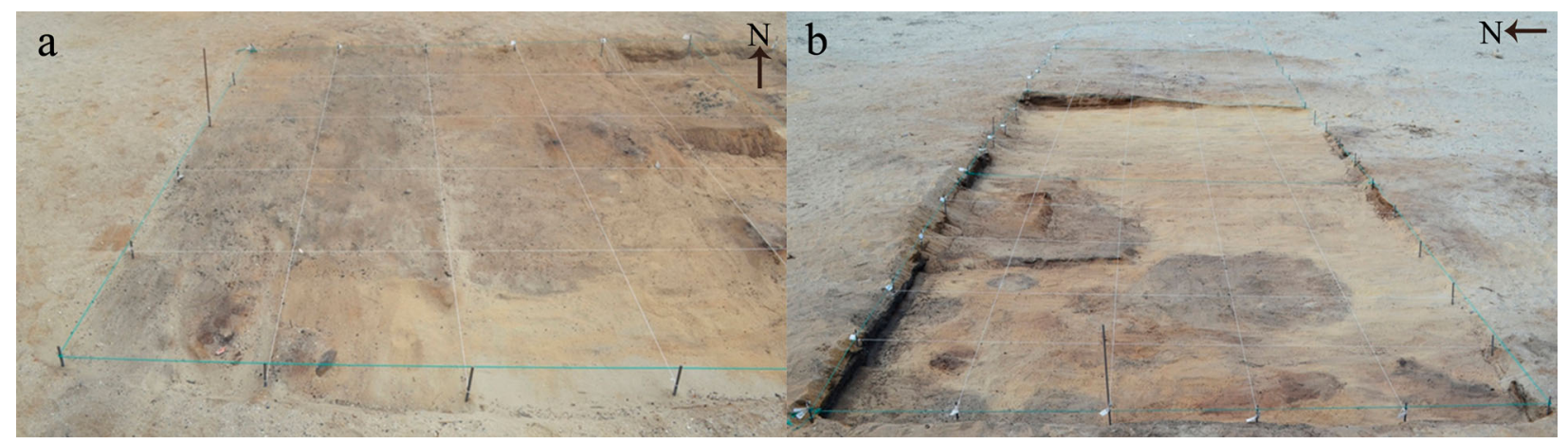

Figure 3. Area 1. (a) Northwards view, level 1; (b) Eastwards view, level 2. ๑ N. Goepfert. 


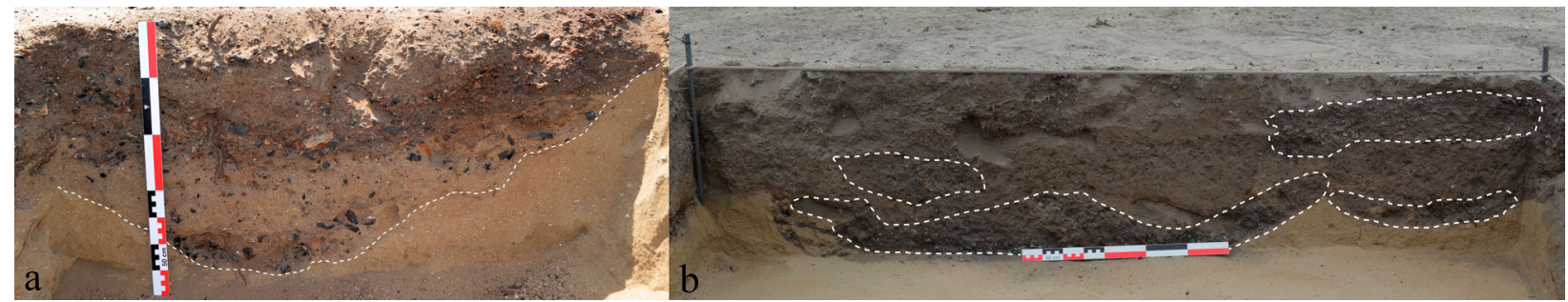

Figure 4. Stratigraphic profile showing the Superposition of hearths in excavation pits. (a) D2; (b) Pit1, hearth remains demarcated by dotted line. ( ) N. Goepfert.

Table 1. Radiocarbon dates for Bayovar-01. Published in Christol et al. (2017).

\begin{tabular}{|c|c|c|c|c|}
\hline Feature & $\begin{array}{c}\text { Radiocarbon } \\
\text { age (BP) }\end{array}$ & $\begin{array}{l}\text { Calibrated } \\
\text { date } \\
(2 \sigma) \text { cal AD }\end{array}$ & $\begin{array}{c}\text { Dated } \\
\text { material }\end{array}$ & $\begin{array}{l}\text { Lab } \\
\text { code }\end{array}$ \\
\hline Pit1 - upper & $1362 \pm 29$ & $617-760$ AD & Charcoal & UBA-23689 \\
\hline Pit1 - lower & $1356 \pm 30$ & $622-763$ AD & Charcoal & UBA-23690 \\
\hline Area 1 & $1418 \pm 29$ & 586-661 AD & Charcoal & UBA-23691 \\
\hline $\begin{array}{c}\text { Area 1-C4 - } \\
\text { upper }\end{array}$ & $1326 \pm 29$ & $651-766$ AD & Charcoal & UBA-23693 \\
\hline $\begin{array}{l}\text { Area 1-C4 - } \\
\text { lower }\end{array}$ & $1400 \pm 29$ & $601-667$ AD & Charcoal & UBA-23694 \\
\hline Structure 2 & $1466 \pm 32$ & $547-646$ AD & $\begin{array}{l}\text { Wooden } \\
\text { post }\end{array}$ & UBA-23695 \\
\hline Structure 2 & $1779 \pm 28$ & 489-697 AD & Shell & UBA-25554 \\
\hline
\end{tabular}

took advantage of the lagoon's abundant resources present, most likely transporting their products to other areas via camelid caravans (Goepfert et al. 2016, forthcoming). The superposed hearths registered during the excavations of the 'processing area' indicate multiple combustion episodes through time, but limited within a rather short period as shown by the dates obtained from Pit 1 and Area 1 (Table 1). These elements suggest that fish were more or less continually processed throughout the settlement's short occupation.

\section{Material and Methods}

\section{Sampling and Recovery}

The material collected was registered for each square metre. Three features from the processing area were sampled for charcoal analyses. In Area 1, a pit was excavated in the units C4 and D2 which correspond to two very large hearths (Figures 3 and 4(a)). Pit 1 was excavated $20 \mathrm{~m}$ to the northeast of the Area 1, yielding the remains of several hearths (Figure 4(b)). In addition, a pit (Pit 4) was excavated into the remains of a small hearth associated with Structure 2.

All of the sediment was collected for each unit. Each sample was then dry sieved with a $1 \mathrm{~mm}$ mesh and all material recovered. These were then separated for their respective analyses (charcoal, seeds, fish bones, pottery fragments, etc.). Random sub-samples of charcoal from each feature were separated in the field (Table 2) and then exported under the permissions obtained from the Peruvian Ministry of Culture (No 093-2014VMPCIC-MC) for study (Table 2). A second random sub-sampling was carried out in the laboratory to reduce the volume of charcoal for analysis to a more manageable and comparable sample size across all of the features, using a riffle box as recommended by Pearsall (2000). Only fragments superior to $4 \mathrm{~mm}$ were analysed in order to limit the risk of under or over-representation of different taxa due to differential fragmentation (Chabal et al. 1999; Chrzavzez et al. 2014). Approximately $50 \mathrm{~g}$ of charcoal was studied from each feature, corresponding to a quantity of ca. 200 observed charcoals for each. The material from the feature Pit 4 yielded only 167 analysable charcoal fragments (Table 2). Due to the perceived uniformity of the stratigraphy, the charcoal studied from each feature was analysed as a single sample, including the material of multiple hearth remains that were combined into a single sample for each feature. Therefore, each sample presents data regarding the sum of all combustion for each feature, but not for individual combustion episodes or hearth remains.

\section{Charcoal Analysis}

Taxonomic identification of the charcoal was carried out with a reflected light microscope. The main reference for identification was the Peruvian wood charcoal reference collection and atlas, created by Moutarde (2006). Various morphological and other characteristics of each observed charcoal fragment were also recorded, including degree of ring curvature, presence of anatomical elements as pith and/or bark, indicators of wood degradation and presence/intensity of vitrification. In most of the charcoal fragments, as growth rings boundaries were not distinct, ring curvature was estimated by the angle of the rays, and categorised as 'strongly curved', 'moderately curved' and 'weakly curved', as proposed by Marguerie and Hunot (2007; Figure 5(a-c)). Fragments where curvature could not be estimated were not included in this analysis. Ring curvature by itself is not sufficient to accurately determine the diameter of the wood used as fuel, as any large $\log$ can yield fragments of varying degrees of curvature (Théry-Parisot et al. 2011). In the present study, this characteristic is used simply to compare general trends among the different features. The presence of pith tissue was observed, which helps to highlight the 
Table 2. Sampling of charcoal and studied sub-sample for each feature.

\begin{tabular}{|c|c|c|c|c|c|c|}
\hline Context & & Total mass & $\begin{array}{l}\text { Sub-Sampled mass } \\
\text { (exported) }\end{array}$ & $\begin{array}{l}\text { Sub-sampled mass } \\
\text { (laboratory) }\end{array}$ & $\begin{array}{l}\text { Analysed subsampled mass (fragments > } \\
\qquad 4 \mathrm{~mm} \text { ) }\end{array}$ & $\begin{array}{l}\text { Analysed } \\
\text { charcoals }\end{array}$ \\
\hline & Pit1 & $17.385 \mathrm{~kg}$ & $1000 \mathrm{~g}$ & $67.427 \mathrm{~g}$ & $65.618 \mathrm{~g}$ & 250 \\
\hline Area 1 & D2 & $5.823 \mathrm{~kg}$ & $500 \mathrm{~g}$ & $65.331 \mathrm{~g}$ & $55.834 \mathrm{~g}$ & 220 \\
\hline Area 1 & $\mathrm{C} 4$ & $3.207 \mathrm{~kg}$ & $500 \mathrm{~g}$ & $42.024 \mathrm{~g}$ & $39.62 \mathrm{~g}$ & 203 \\
\hline Structure 2 & Pit4 & $0.702 \mathrm{~kg}$ & $100 \mathrm{~g}$ & $47.094 \mathrm{~g}$ & $47.033 \mathrm{~g}$ & 167 \\
\hline
\end{tabular}

occurrence of juvenile wood (Figure 5(d)). Very small twigs were identified as well, presenting both pith and bark (Marguerie and Hunot 2007). The presence of bark on fragments with strong ring curvature was also an indicator of a smaller diameter. Concerning wood degradation, the presence of fungal hyphae, located most commonly within vessel elements, was considered a marker of fungal attacks suffered by the wood before its carbonisation (Figure 5(e,f)). Fungal attacks occur mostly in dead or dying wood and their presence in charcoal can be an indicator of gathering of dead wood as a foraging strategy, and/or the practice of storing otherwise healthy wood for a period of time prior to combustion (Marguerie and Hunot 2007; Schweingruber 2007; Moskal-del Hoyo, Wachowiak, and Blanchette 2010; Caruso Fermé 2013). Charcoal vitrification corresponds to the fusion of the anatomical constituents of the wood, which can lead to the homogenisation of the visible structure (Marguerie and Hunot 2007). The conditions affecting this phenomenon have yet to be clearly identified, with experimental studies producing different results (Fabre 1996; Scheel-Ybert 1998; Théry-Parisot 2001; Carrión 2005; Allué, Euba, and Solé 2009; McParland et al. 2010; Caruso Fermé 2013). Nevertheless, it is thought that vitrification may result at least in part from the wood's condition prior to burning, such as humidity, as in green wood (Scheel-Ybert 1998), and/ or combustion conditions themselves, such as the duration of combustion phases, abrupt changes in

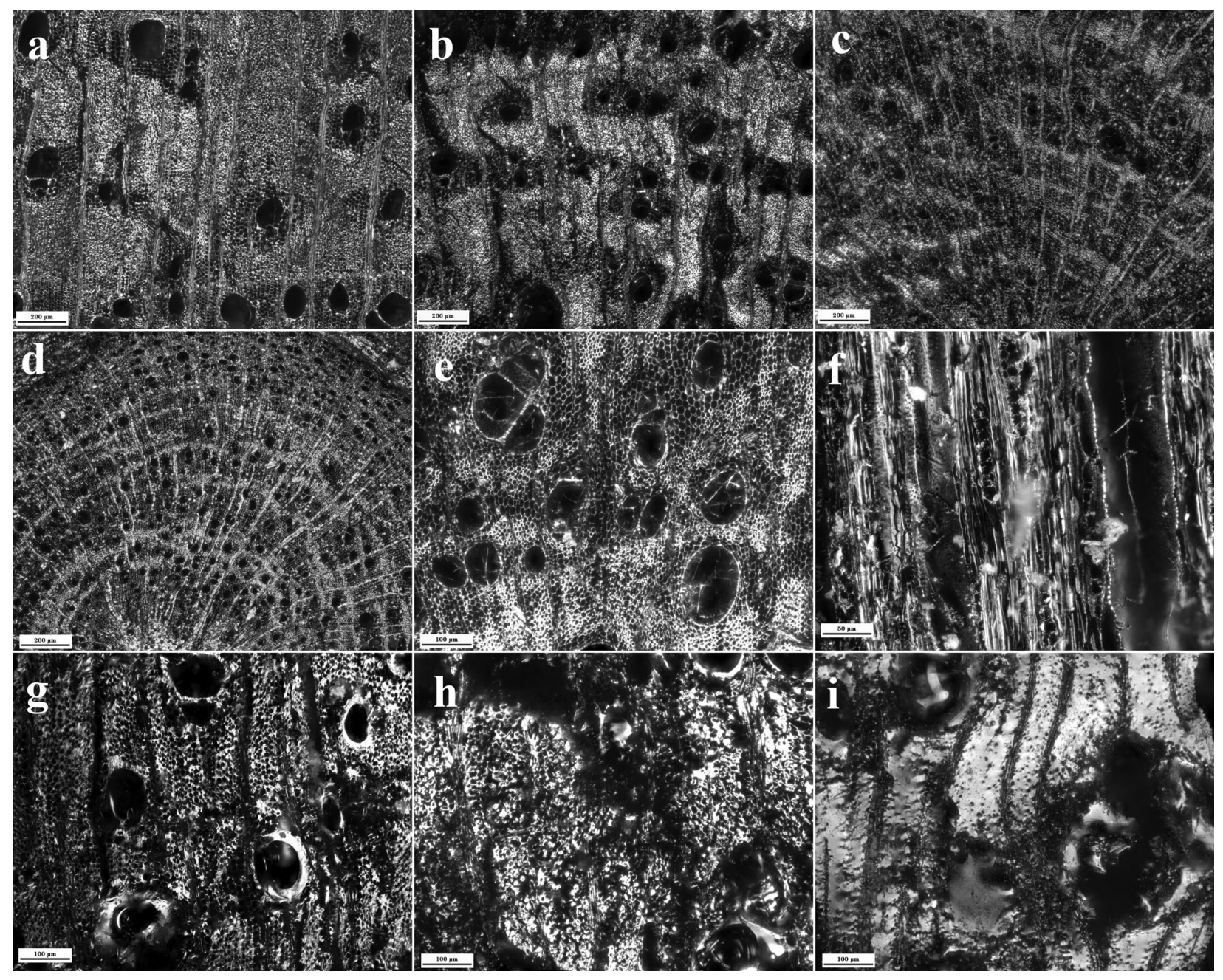

Figure 5. Reflective light microscope micrographs showing observed criteria on Prosopis/Vachellia. (a) Weakly curved rings; (b) Moderately curved rings; (c) Strongly curved rings; (d) Charcoal fragment showing both pith and bark; (e) Fungal hyphae in vessel elements (transverse view); (f) Fungal hyphae in vessel elements (longitudinal tangential view); (g) Charcoal showing a low degree of vitrification; (h) Charcoal showing a moderate degree of vitrification; (i) Charcoal showing a high degree of vitrification. 


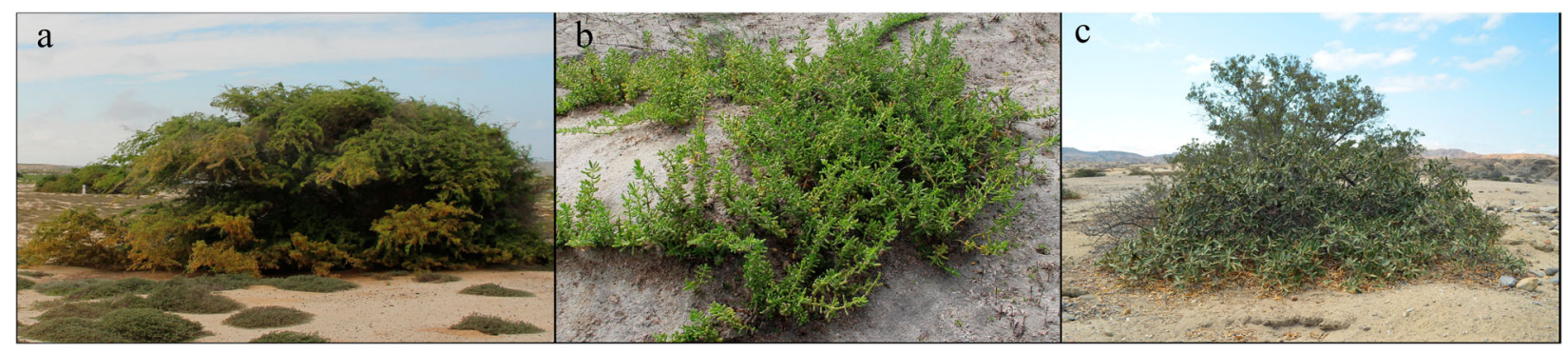

Figure 6. Principal taxa discussed in the study. (a) American carob tree (Prosopis pallida); (b) 'vidrio' (Batis maritima); (c) 'Sapote' (Colicodendron scabridum).

combustion conditions (Beresford-Jones et al. 2010), or a reducing atmosphere with little oxygen (Carrión 2005). Different degrees of vitrification were characterised by the presence and extent of homogenised tissue, as 'high', 'moderate', 'low', or 'absent' (Figure 5(g-i)). The evaluation of different degrees of vitrification may provide information regarding the initial state of the wood used as fuel, as well as about the combustion itself.

\section{Results}

\section{Taxonomic Identification}

The anthracological spectrum of all features is dominated by the Fabaceae family, subfamily Mimosoideae (between $94 \%$ and $97 \%$ of the assemblage). Distinguishing among some of the taxa within this subfamily based only on the cellular structure is extremely difficult due to significant intraspecific variability and interspecific proximity (Moutarde 2006, 2008; Goldstein 2007; Froyd et al. 2010). Relying only on visual observation, it is possible to distinguishing broadly between the genera Prosopis and Vachellia (formerly part of the Acacia genus, corresponding to its American species). Today, the only Mimosoideae species present in the closer vicinity of Bayovar-01 is Prosopis pallida, the American carob tree also called algarrobo (Figure 6(a)). Nevertheless, we cannot exclude the possibility that specimens of the genus Vachellia, notably Vachellia macracantha and Vachellia aroma (var. huarango) were present in the past, as both are known to be part of the Peruvian tropical dry forest ecosystem, of which P. pallida is the backbone (Goldstein 2007). Following the examples of Moutarde $(2006,2008)$ and Froyd et al. (2010) we have chosen to group these specimens as a Prosopis/ Vachellia taxa (Table 3), as both share the same habitat and wood characteristics, being primarily lowland xerophytic trees and shrubs, found along the Peruvian coastal region, and having dense wood, considered to be high quality fuel (Goldstein 2007; Mostacero León, Mejía Coico, and Gamarra Torres 2009; Goldstein and Shimada 2013). Batis maritima, one of the two species of the only genus of the Bataceae family, was
Table 3. Identified charcoal fragments for each feature (NISP).

\begin{tabular}{|c|c|c|c|c|c|c|}
\hline \multicolumn{2}{|c|}{ Taxa } & \multicolumn{4}{|c|}{ Features } & \\
\hline Family & Taxon & Pit1 & C4 & D2 & Pit4 & \\
\hline Asteraceae & & & 1 & & 1 & \\
\hline Bataceae & B. maritima & 2 & 3 & 1 & & 6 \\
\hline Boraginaceae & & & 1 & & & \\
\hline Capparaceae & C. scabridum & & & & 3 & 3 \\
\hline Fabaceae & Prosopis/Vachellia & 173 & 190 & 149 & 116 & 628 \\
\hline Monocotyledone & & 3 & & 8 & & 11 \\
\hline Unidentified & & 72 & 25 & 45 & 47 & 189 \\
\hline Total & & 250 & 220 & 203 & 167 & 840 \\
\hline
\end{tabular}

also identified in the three processing area features (Table 3). It is a subtropical and tropical shrub, inhabiting the margins of saltpans, marshes and mangrove swamps, and characterised by succulent leaves (Lonard, Judd, and Stalter 2011; Figure 6(b)). In addition to these taxa, two charcoal fragments were identified to the family level only, one as being from the Asteraceae family and the other from the Boraginaceae family, the latter being most likely Cordia sp. or Heliotropium sp. Several charcoal fragments from monocotyledon plants were also noted (Table 3).

The anthracological spectrum of the domestic feature's assemblage (Pit 4, Table 3) was also dominated by Prosopis/Vachellia, but Colicodendron scabridum, also called 'sapote', of the Capparaceae family was also identified. It is a xerophytic shrub, one of the most ubiquitous in the vicinity of the site today, and it is commonly found along the margins of the tropical dry forest (Goldstein 2007; Figure 6(c)). Due to the significant taxonomic homogeneity among the different assemblages, primarily the result of the systematic predominance of a single taxon, it became necessary to consider other, non-taxonomic attributes, such as the morphology and localised environmental markers to identify possible inter-context variability in the wood charcoal samples, potentially linked to their source areas, use, etc.

\section{The Processing Area (Features Pit1, C4 and D2)}

Charcoal from the features in the processing area exhibited similar percentages of different ring curvature classes, roughly a third of each sample for each class (Figure 7). The presence of very small diameter 
Estimated ring curvature

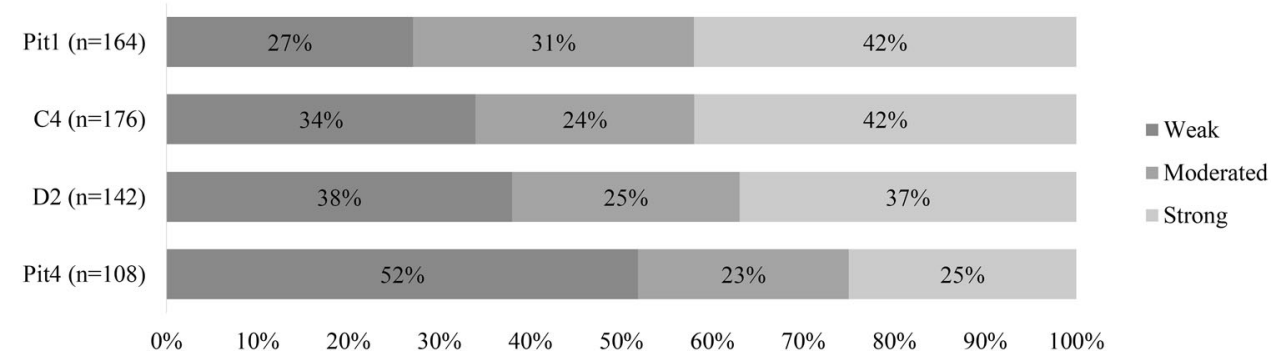

Figure 7. Prosopis/Vachellia observed charcoal fragments distribution by estimated ring curvature.

(as small as $2 \mathrm{~mm}$ ) charred twigs and charcoal fragments with a complete pith and/or bark (Figure 8), and charcoal with weak ring curvature, suggestive of large diameter trunks or large branches, shows that the size range of wood burned was very wide. Instances of complete pith present within fragments of small diameter $(2-8 \mathrm{~mm})$ may also be indicative of the presence of small diameter branches. However, they could also be part of fragmented larger branches. Without statistical analysis of the ensemble of fragments within the samples, the proportion of those fragments belonging to small calibre and large calibre branches cannot be estimated. Nevertheless, given the morphology of the fragments and the fragmentation pattern of the taxa observed we suspect that they represent principally small diameter branches. Fungal hyphae was observed in approximately a third (28-46\%) of the assemblages for each feature, primarily present inside vessel elements (Figure 9). Various degrees of vitrification were observed in the majority of charcoal fragments from all three processing features, also showing a fairly even distribution among the different classes (Figure 10). The results of the analysis of these different criteria show great homogeneity among the three features of the processing area (Figures 7-10).

\section{Domestic Feature (Pit 4)}

The results obtained from the domestic feature showed some similarities with those from the features of the processing area, but also some very clear differences. The majority of the charcoal was characterised by weak ring curvature, and small branches were found in a slightly lesser percentage. In contrast to the processing features, twigs and other small diameter wood were absent (Figures 7-10). The evaluation of

\section{Small caliber markers}

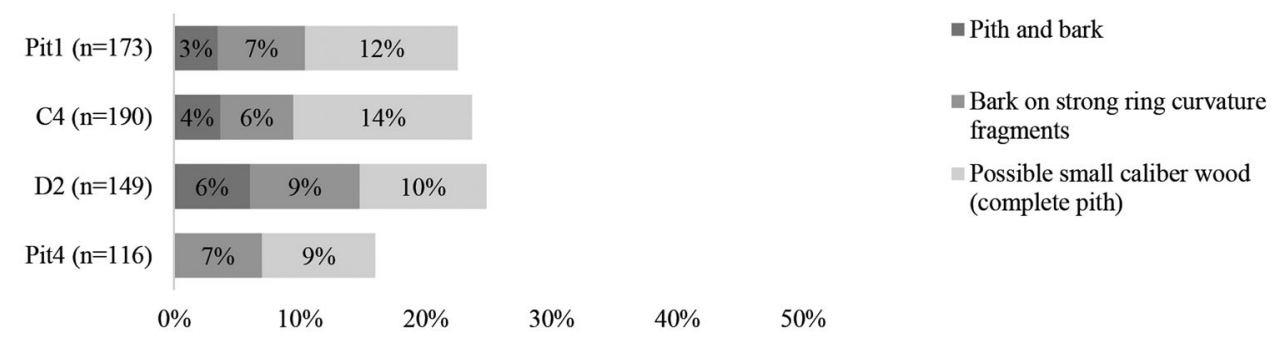

Figure 8. Percentage of Prosopis/Vachellia observed charcoal fragments presenting small calibre markers.

Presence of fungal hyphae

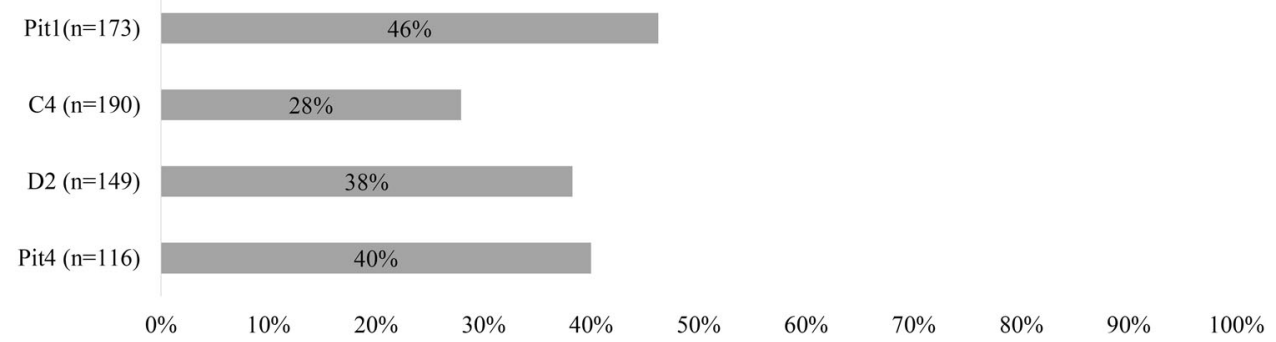

Figure 9. Percentage of Prosopis/Vachellia observed charcoal fragments presenting fungal hyphae. 
Perceived degree of vitrification

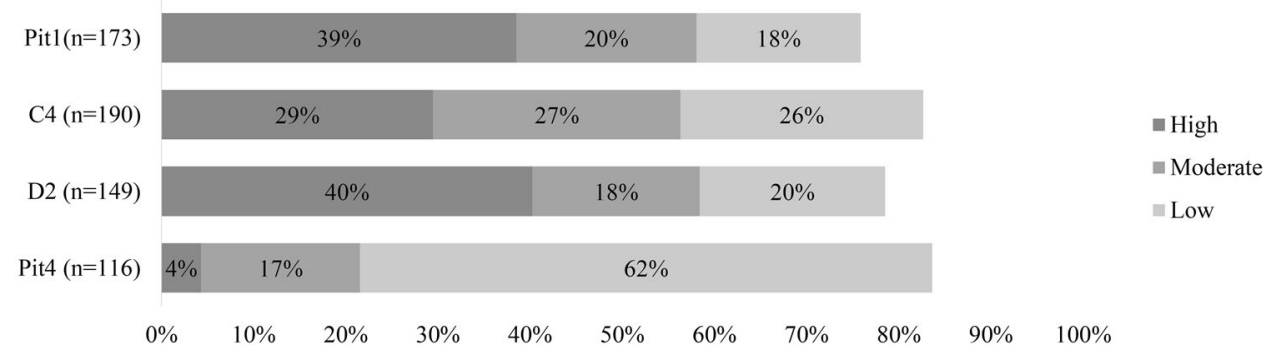

Figure 10. Prosopis/Vachellia observed charcoal fragment distribution by perceived degree of vitrification.

vitrification in the charcoal also yielded different results for the domestic hearth. While there was a similar overall percentage of charcoal fragments with traces of vitrification, the distribution of the different classes was distinct from that of the processing area, with the majority of domestic charcoal showing a weak degree of vitrification (Figure 10). The presence of fungal hyphae within the charcoal occurred at similar percentages in samples from both the domestic and processing features (Figure 9).

\section{Discussion}

\section{Ancient Environment}

While the small sample size and the nature of the contexts studied (concentrations of material related to a highly specialised activity that was most likely associated with highly selective wood use) are not well-suited for a systematic reconstruction of the past vegetation (Chabal 1992; Chabal et al. 1999; Théry-Parisot 2001), we can nevertheless propose some suggestions regarding certain characteristics of the ancient landscape, to be further studied in future work. First, the significant quantity of charcoal recovered from the different features, appearing to consist primarily of Prosopis/Vachellia, does not correspond to the current landscape, where this kind of vegetation does exist but is rare. This finding is in concordance with the existing evidence that environmental conditions around Bayovar-01 were quite different during the Pre-Hispanic occupation. The presence of a large palaeo-lagoon, resulting in increased water availability (Christol et al. 2017), would have supported a dry tropical forest, like that found today on the periphery of the Sechura desert (and elsewhere along the Peruvian coast like the 'Bosque de Pomac' in the Lambayeque region), where water is more abundant (La Torre-Cuadros and Linares Palomino 2008). This dry tropical forest, whose main components are Mimosoideae, and P. pallida in particular, could have provided all of the firewood necessary for the different activities carried out in Bayovar-01, particularly for the processing of large quantities of fish. In view of the massive scale of the settlement's activities, as well as their apparently expedient nature, it is likely that the settlers selected a location with abundant resources (including fuel wood) already at hand. So, while the possibility that fuel wood resources could have been obtained over longer distances cannot be completely dismissed, it is more probable that they were collected locally. The only palaeo-environmental study carried out in this area indicates proxy data that in the past the local area around the palaeo-lagoon was characterised by tropical vegetation (even a mangrove type vegetation) during the first millennium AD (Christol et al. 2016, 2017). Therefore, our hypothesis with regards to fuel wood acquisition cannot be considered directly with local palaeo-vegetation data.

An alternative source of information regarding past vegetation may come from ethno-historic accounts from the 16th century. Explorers and chroniclers, such as Pedro Cieza de Léon, Martín de Morúa (Rostworowski 1981) and Miguel de Estete (Moutarde 2006) note the presence of dense algarrobo forests along the coastal regions of Peru. For the colonial period, Rostworowski's (1981) study of written sources depicts intense deforestation on the coast, linked with an increasing demand for building materials and ever growing firewood demand and charcoal production. These activities were continually practiced from the 16th century until the twentieth century (Rostworowski 1981). Both the intensity and length of these activities may attest to the great initial availability of wood and thus the extent and abundance of ancient forests along the coastal region of Peru during preColumbian times. Both Moutarde (2006) and Goldstein (2007) conclude that it is very likely that foresttype vegetation was much more abundant on the coastal region in pre-Columbian than it is now.

\section{Wood Taxa Use}

Both Prosopis and Vachellia (particularly V. macracantha) constitute excellent fuel wood, having a high caloric value while also being slow-burning (Goldstein 2007; Goldstein and Shimada 2013). They seem to have been the firewood of choice for many activities in pre- 
Hispanic times (Moutarde 2008), including highly specialised crafts such as metal working and pottery firing (Goldstein and Shimada 2013). Their use continued well into the colonial era (Rostworowski 1981) and is still present today (Moutarde 2006; Goldstein 2007). Trees and shrubs from the Capparaceae family, such as C. scabridum, were also used as firewood in the past and continue to be today. While their caloric value is similar to that of Prosopis and Vachellia, they are more rapidly consumed by combustion (Moutarde 2006; Goldstein and Shimada 2013). It seems clear that the inhabitants of Bayovar-01 were highly selective of their fuel wood, particularly for the fish processing activities. Goldstein and Shimada (2013) demonstrate that the preferential use of certain taxa as firewood for specific crafting activities seems to depend on their physical properties and the combustion conditions that are best suited to the activities in question. Fish processing at Bayovar-01 appears to follow this logic, with a clear selection of Prosopis/Vachellia wood, while C. scabridum seems not to have been used for this particular activity.

Based on our current data we cannot exclude the possibility that unknown taphonomic processes that result in differential preservation among the wood taxa may account for the lack of C. scabridum in the processing features (Théry-Parisot, Chabal, and Chrzavzez 2010). Nevertheless, it is interesting to note that in almost all of the activities studied by Goldstein and Shimada (2013), Capparaceae was present in the charcoal assemblages. Batis maritima is widely available along the coast of the Sechura Desert, but its presence in the fish processing features assemblages seems unusual as it is a creeping shrub that does not provide large quantities of useful firewood and whose succulent leaves are poorly adapted to burning. The highly superior and abundant Prosopis/Vachellia wood seems a much more logical choice for fuel. Nevertheless, the poor combustion qualities of $B$. maritima may be an indicator of how fish were processed at the site. If not previously well dried, the water-rich leaves would have most likely created a smoky fire, suggesting that this was potentially a form of fish preparation carried out at Bayovar-01. The use of Prosopis/ Vachellia is a very suitable wood for smoking practices, used usually when dry. Preference for a dense fuel wood is consistent with traditional smoking practices cross-culturally (Le Gall 1938; Alix and Brewster 2004; Feka and Manzano 2008; Obodai et al. 2009).

This suggestion raises certain issues. First of all, smoking of fish is not a known practice for the pre-Hispanic Peruvian coast, but it may well be a lost tradition in the region. Secondly, although post holes were identified on the eastern part of Area 1 that could indicate the presence of a structure, the lack of well-defined smoking structures may cast some doubt on this interpretation. This needs to be further tested against the study of the fish remains, particularly to see which parts of the animals were prepared. Finally, the presence of fairly abundant camelid dung in the combustion contexts indicates that it was used as fuel, a practice commonly known in the Andes with the name of 'taquia' (Sillar 2000). The use of this particular fuel would seem curious for smoking practices as it would release a peculiar scent, but it has been noted that taquia's scent is not a problem for its use in culinary activities in the Andes (Sillar 2000). Smoking, and particularly the use of camelid faeces, could have also been a strategy to repel mosquitos and other insects around the palaeo-lagoon (C. Alix personal communication, January 26, 2018).

\section{Gathering Strategies}

The percentage of charcoal fragments presenting markers of fungal attacks suggest that at least a portion was obtained through foraging of dead wood and/or that the wood was stored for a length of time before being used. The gathering of deadwood represents an important part of firewood procurement in coastal Peru and in modern communities of the Lurín valley and the site of Sialupe (Novoa Goicochea 1998; Moutarde 2006; Goldstein 2007). Nevertheless, in all features studied, the majority of the charcoal fragments do not show traces of fungal attack (Figure 10). Thus, it seems likely that a mixed strategy of firewood gathering was used, combining both the gathering of deadwood and tree felling, possibly with the storage of a portion of the firewood. This also points to a local gathering of the wood, indeed if firewood was unavailable locally and had to be obtained over longer distances, it would probably have been stored prior to use and the assemblages might be expected to show a more significant presence of fungal hyphae. It is also possible that the traces of fungal attacks correspond to significant use of green wood already contaminated. Nonetheless, the firewood used for smoking practices is usually dry (Le Gall 1938; Alix and Brewster 2004; Obodai et al. 2009). The distribution of charcoal fragments within the three categories of ring curvature from the three processing features suggests the use of a variety of wood diameters, possibly as a result of the use of various tree parts (twigs, branches, trunks).

\section{Consistent Fish Processing Practices}

The homogeneity of the anthracological spectra among the processing area features, as well as the similar presence of fungal hyphae, ring curvature and small diameter wood show consistent practices for the gathering and management of firewood to be used for fish processing (Figure 7-10). Furthermore, this homogeneity among the processing features is also observed for 
the vitrification of the charcoal (Figure 10). Even if the specific conditions resulting in this phenomenon remain unknown, the similarity observed among the features indicates comparable characteristics of the firewood used, in addition to the combustion conditions. Our results thus point to standardised practices concerning fuel and combustion management for the processing activities. Indeed, the homogeneity of the results among the features is best explained by practices and characteristics of fuel and combustion conditions that were consistent not only globally among the features, but most likely for the individual combustion episodes themselves as well.

In contrast, the results observed for the domestic hearth point to a different set of fuel management practices and fire used for a distinct type of activity. The ring curvature data indicates a difference in the firewood diameters for domestic use. Specifically, they reveal a clear tendency towards more weak curvature fragments, possibly the result of a greater proportion of large wood diameters, which is further supported by the lower percentage of identified small diameter fragments and the absence of twigs. This might be due to the use of different proportions of wood diameters as fuel. An alternate possibility is that the domestic context's combustion conditions favoured the conservation of larger diameter fragments over smaller ones. In either case, it indicates different practices occurred between the fish processing contexts and the domestic one. Vitrification offers an additional sign of these differences, with a clear contrast between the domestic and processing features that seems to indicate different overall firewood and combustion characteristics. The absence of Capparaceae wood in all three fish processing contexts, while present in the small domestic hearth sample, suggest potential differences in the use of wood taxa between these different activities. This presence, even if in very small quantities, reveals the availability of Capparaceae wood, known to have been used as a common source of firewood (Moutarde 2006; Goldstein 2007). Thus its absence in contexts associated with fish processing activities seems significant.

It seems likely that the standardised practices glimpsed through the analysis of the charcoal remains of the processing features are closely linked to the fish processing, which may involve preservation through smoking, a practice characterised by precise parameters. This may also explain the differences observed between the charcoal studied from the processing area, and that of the domestic hearth, which resulted from distinct activities.

\section{Conclusion}

Taxonomic identification of charcoal from all four features points to the preferred use of Prosopis/Vachellia firewood. This is likely due to its characteristics as an excellent fuel, but it also suggests its abundance in the vicinity of the settlement. The presence of an ancient lagoon in the area further supports the existence of an ancient dry tropical forest in the vicinity of the site of Bayovar-01 at the time of its occupation. The use of taxa such as B. maritima, typically not wellsuited as a fuel, was observed for the fish processing activities, and may be an indicator of smoking. Conversely, the use of other taxa, as C. scabridum, an adequate fuel that is also present in the dry forest ecosystem, seems to have been deliberately rejected for these activities.

The homogeneity of the fuel and combustion management, in addition to taxa preferences, indicate that the parameters of the fish processing activities were carefully controlled and replicated by the craftsmen, most likely in order to obtain a product of standardised quality. This would mean that the occupants of the settlement were not only specialised fishermen, but they also had extensive knowledge of large-scale fish processing practices. This finding reinforces the hypothesis about the function of the site of Bayovar01 as a specialised settlement dedicated to the exploitation of fish resources available in the lagoon and their processing in large quantities, to be later transported to other areas via llama caravans. The fuel resources used were most likely obtained locally in an ancient dry tropical forest formation, using a mixed strategy of expedient firewood gathering.

This study provides a first insight into the economic practices at Bayovar-01 and demonstrates more broadly the potential for taxonomic and morphological wood charcoal analysis for the further understanding of the human practices revolving around the use of firewood. It seems likely that such applications, if carried out on a larger and more representative sample, and with several more studied features, could provide invaluable insights into the practices and lives of the inhabitants of pre-Hispanic Peru.

\section{Acknowledgements}

The fieldwork was possible thanks to the support of the Peruvian Ministry of Culture. We thank Dr. José Vega and the Vale-Misky Mayo Company for providing free access to the Bayovar-01 site. We thank also Aurélie Salavert and Margareta Tengberg (UMR 7209, MNHN), for access to Fanny Moutarde's charcoal reference collection, and the archaeobotany laboratory at the Maison Archéologie et Ethnologie in Nanterre, where the study was conducted. We also thank all the archaeologists, students and staff who worked in the excavations, particularely Carlos Gutiérrez Vereau.

\section{Disclosure statement}

No potential conflict of interest was reported by the authors. 


\section{Funding}

This work was supported by the French Ministry of Foreign Affairs with additional contributions from the Université Paris 1, Panthéon-Sorbonne (Paleosech Grant), the Académie des Inscritptions et Belles-Lettres (Carroll Award), and BGL Arqueología.

\section{Notes on contributors}

Nicolas Bermeo is a PhD student of archaeology at the university of Paris 1 Panthéon-Sorbonne. His doctoral research focuses on the archaeobotanical remains discovered on the recent excavations carried out by the Desert of Sechura Archaeological Project in the extreme northern coast of Peru.

Michelle Elliott is Associate Professor of Archaeology at the Université Paris 1, Panthéon-Sorbonne. She also co-directs the Environmental Archaeology Master's program and directs the university's Laboratory of Archaeobotany. Dr. Elliott specializes in the archaeobotany of highland Prehispanic Mexico, particularly in West and Northwest Mesoamerica. She has a number of publications focused on the relationship between environmental factors and the movements of Mesoamerican agricultural societies throughout the semi-arid northern frontier over the last 2000 years. Her current research is dedicated to the use of plant macro and microremains to better understand the management of landscapes and resources by ancient societies in the Basin of Mexico. This approach focuses particularly on the study of wood and wood charcoal remains as indicators of local environmental conditions, as well as the organization of wood resource economies.

Nicolas Goepfert is an investigator at the CNRS (the French national centre for scientific research) and the director with Belkys Gutiérrez of the Desert of Sechura Archaeological Project. He is an archaeologist and zooarchaeologist specializing in the northern coast of Peru. His research deals with funerary and sacrificial practices linked to animals, especially South American camelids, and the adaptation of human and animals to the desert Pacific coast of Peru. He has published several articles on the topic, and he is co-editor, with S. Vásquez, C. Clément and A. Christol, of Las sociedades andinas frente a los cambios pasados y actuales: dinámicas territoriales, crisis, fronteras y movilidades (IFEA-LabEx DynamiTe-UNT, 2016).

Belkys Gutiérrez León is a Master in archaeology and director of the Desert of Sechura Archaeological Project with Nicolas Goepfert. Her research areas are focused on the Mochica culture and she was co-director with con C. Chauchat of the Uhle Platform excavations between 1999 y 2009. She has published several articles and she is currently the director of the Archaeological Project Cerro Santa Ana in the Chicama valley.

Vásquez Sánchez Segundo is a Professor of Archaeology in the Social Sciences Faculty of the Universidad Nacional de Trujillo (UNT). His research areas are focused in the Formative Period of Peru, the Initial Period ceramics, and the Mochica Culture. He was founder director of the Archaeological Program El Brujo Complex between 1990 and 2007, and he is currently the director of the Archaeological Project Cerro Santa Ana in the Chicama valley. He has published several articles, and he is co-editor, with N. Goepfert, C. Clément and A. Christol, of Las sociedades andinas frente a los cambios pasados y actuales: dinámicas territoriales, crisis, fronteras y movilidades (IFEALabEx DynamiTeUNT, 2016).

\section{ORCID}

Nicolas Bermeo (D) http://orcid.org/0000-0002-9547-0878

Michelle Elliott (D) http://orcid.org/0000-0002-0617-5982

Nicolas Goepfert (i) http://orcid.org/0000-0002-6155-1856

\section{References}

Alix, C., and K. Brewster. 2004. "Not All Driftwood is Created Equal: Wood Use and Value along the Yukon and Kuskokwim Rivers, Alaska." Alaska Journal of Anthropology 2 (1-2): 48-65.

Allué, A., I. Euba, and A. Solé. 2009. "Charcoal Taphonomy: The Study of the Cell Structure and Surface Deformations of Pinus sylvestris Type for the Understanding of Formation Processes of Archaeological Charcoal Assemblages." Journal of Taphonomy 7 (2-3): 57-72.

Beresford-Jones, D. G., K. Johnson, A. G. Pullen, A. J. E. Pryor, J. Svoboda, and M. K. Jones. 2010. "Burning Wood or Burning Bone? A Reconsideration of Flotation Evidence from Upper Palaeolithic (Gravettian) Sites in the Moravian Corridor." Journal of Archaeological Science 37: 2799-2811.

Cardenas, M., C. Huapaya Manco, and J. Deza Rivasplata. 1991. Arqueología del Macizo de Illescas, Sechura-Piura: excavaciones en Bayóvar, Nunura, Avic, Reventazón y Chorrillos. Lima: Pontificia Universidad Católica del Perú. Dirección Académica de Investigación.

Cardenas, M., J. Vivar Anaya, and B. Huapaya Cabrera. 1993. Materiales arqueológicos del Macizo de Illescas: SechuraPiura: excavaciones en Bayóvar, Nunura, Avic, Reventazón y Chorrillos. Lima: Pontificia Universidad Católica del Perú. Dirección Académica de Investigación.

Carrión, Y. 2005. La vegetación mediterránea y atlántica de la Península Ibérica. Nuevas secuencias antracológicas. Servicio de Investigación Prehistórica. Valencia: Diputación Provincial de Valencia.

Caruso Fermé, L. 2013. Los recursos vegetales en arqueología: estrategias de muestreo y estudios del material leñoso. Buenos Aires: Dunken.

Chabal, L. 1992. "La représentativité paléo-écologique des charbons de bois archéologiques issus du bois de feu." Bulletin de la Société Botanique de France. Actualités Botaniques 139 (2-4): 213-236.

Chabal, L., L. Fabre, J.-F. Terral, and I. Théry-Parisot. 1999. "L'anthracologie." In La Botanique, edited by A. Ferdière, 43-104. Paris: Errance.

Christol, A., N. Goepfert, P. Béarez, P. Wuscher, and B. Guitiérrez and. 2016. "Étude géoarchéologique multiproxy de la paléo-lagune Las Salinas dans le désert de Sechura (Pérou)." Les nouvelles de l'archéologie 142: 43-48.

Christol, A., P. Wuscher, N. Goepfert, V. Mogollón, P. Béarez, B. Guitiérrez, and M. Carré. 2017. “The Las Salinas Palaeolagoon in the Sechura Desert (Peru): Evolution during the last Two Millennia." The Holocene 27 (1): 26-38.

Chrzavzez, J., I. Théry-Parisot, G. Fiorucci, J.-F. Terral, and B. Thibaut. 2014. "Impact of Post-Depositional Processes on Charcoal Fragmentation and Archaeobotanical Implications: Experimental Approach Combining Charcoal Analysis and Biomechanics." Journal of Archaeological Science 44: 30-42.

Collin-Delavaud, C. 1984. Las regiones costeñas del Perú septentrional: ocupación humana, desarrollo regional. 
Lima: Centro de Investigación y Promoción del Campesinado. Pontificia Universidad Católica del Perú, Fondo Editorial.

Fabre, L. 1996. "Le Charbonnage historique de la chênaie à Quercus ilex L. (Languedoc, France) : conséquences écologiques." PhD diss., Université Montpellier II.

Feka, N. Z., and M. Manzano. 2008. "The Implications of Wood Exploitation for Fish Smoking on Mangrove Ecosystem Conservation in the South West Province, Cameroon." Tropical Conservation Science 1 (3): 222-241.

Ferreyra, R. 1987. "Flora y Vegetación del Perú." In Gran Geografía del Perú: Naturaleza y Hombre, edited by Marc J. Dourojeanni, 3-172. Barcelona: Manfer J. Mejía Baca.

Froyd, C. A., J. A. Lee, A. J. Anderson, S. G. Haberle, P. E. Gasson, and K. J. Willis. 2010. "Historic Fuel Wood Use in the Galápagos Islands: Identification of Charred Remains." Vegetation History and Archaeobotany 19 (3): 207-217.

Goepfert, N., P. Béarez, A. Christol, and B. Gutiérrez. Forthcoming. "Subsistence Economies in Margin Areas with Natural Constraints: Interactions between Social Dynamics, Natural Resource Management and Paleoenvironment in the Sechura Desert, Peru." In New Perspectives on Andean Maritime Communities, edited by G. Prieto and D. H. Sandweiss. Gainesville: University Press of Florida.

Goepfert, N., P. Béarez, A. Christol, B. Gutiérrez, and P. Wuscher. 2014. "The Fishermen of Sechura: Excavations at a Specialised Site from the Early Intermediate Period, Extreme Northern Peru." Antiquity Project Gallery 88 (340): www.antiquity.ac.uk/projgall/goepfert340.

Goepfert, N., A. Christol, B. Gutiérrez, P. Wuscher, P. Béarez, C. Lefèvre, and V. Mogollón. 2016. "La Ocupación Prehispánica del Desierto de Sechura (Perú): Evolución de un Territorio en Margen Frente a los Cambios Medioambientales." In Las Sociedades Andinas Frente a los Cambios Pasados y Actuales: Dinámicas Territoriales, Crisis, Fronteras y Movilidad, edited by N. Goepfert, S. Vasquez, C. Clement, and A. Christol, 171194. Lima: IFEA-LabEx DynamiTe-UNT.

Goldstein, D. J. 2007. "Forests and Fires: A Paleoethnobotanical Assessment of the Impact of Middle Sican Pyrotechnology on the Dry Tropical Forests of the La Leche River Valley, Lambayeque, Peru (950-1050 CE).”PhD diss., Southern Illinois University.

Goldstein, D. J., and I. Shimada. 2013. "An Experimental and Ecological Approach to Modeling Ancient Fuel Use.” In Proceedings of the Fourth International Meeting of Anthracology, Brussels, 8-13 September 2008, Royal Belgian Institute of Natural Sciences, edited by F. Damblon, 121-132. Oxford: Archaeopress.

Johannessen, S., and C. A. Hastorf. 1990. "A History of Fuel Management (A.D. 500 to the Present) in the Mantaro Valley, Peru." Journal of Ethnobiology 10: 61-90.

La Torre-Cuadros, M., and R. Linares Palomino. 2008. "Mapas y clasificación de vegetación en ecosistemas estacionales: un análisis cuantitativo de los bosques secos de Piura." Revista Peruana de Biología 15 (1): 31-42.

Le Gall, J. 1938. Le Fumage du poisson. Paris: Office scientifique et technique des pêches maritimes.

Lonard, R. I., F. W. Judd, and R. Stalter. 2011. "The Biological Flora of Coastal Dunes and Wetlands: Batis Maritima C. Linnaeus.” Journal of Coastal Research 27: 441-449.

Marguerie, D., and J.-Y. Hunot. 2007. "Charcoal Analysis and Dendrology: Data from Archaeological Sites in
North-Western France." Journal of Archaeological Science 34 (9): 1417-1433.

McParland, L. C., M. E. Collinson, A. C. Scott, G. Campbell, and R. Veal. 2010. "Is Vitrification in Charcoal a Result of High Temperature Burning of Wood?” Journal of Archaeological Science 37 (10): 2679-2687.

Moskal-del Hoyo, M., M. Wachowiak, and R. A. Blanchette. 2010. "Preservation of Fungi in Archaeological Charcoal." Journal of Archaeological Science 37 (9): 2106-2116.

Mostacero León, J., F. Mejía Coico and O. Gamarra Torres. 2009. Fanerógamas del Perú: taxonomía, utilidad y ecogeografía. Trujillo: CONCYTEC.

Moutarde, F. 2006. L'évolution du couvert ligneux et son exploitation par l'homme dans la vallée Du Lurín (côte Centrale Du Pérou), de l'Horizon Ancien (900-100 Av. J. -C.) à l'Horizon Tardif (1460-1532 Apr. J. -C.): Approche Anthracologique." $\mathrm{PhD}$ diss. Université Paris 1 Panthéon- Sorbonne.

Moutarde, F. 2008. "Los carbones hablan: un estudio del material antracológico de la Plataforma Uhle, Huaca de la Luna. Un acercamiento a la economía vegetal de la costa norte del Perú en la época mochica." In Arqueología mochica: nuevos enfoques: actas del Primer Congreso Internacional de Jóvenes Investigadores de la Cultura Mochica. Lima, 4 y 5 de Agosto de 2004, edited by L. J. Castillo Butters, H. Bernier, G. Lockard, and J. Rucabado Yong, 295-305. Lima: fondo Editorial. Pontificia Universidad Católica del Perú.

Novoa Goicochea, Z. I. 1998. Ecogeografía de la región costera: "montes costeros": naturaleza y cultura en el desierto. Lima: Pontifica Universidad Católica del Perú. Sociedad Geográfica de Lima: Asociación Pakatnamu.

Obodai, E. A., B. A. Muhammad, G. A. Obodai, and E. Opoku. 2009. "Effect of Fuel Wood on the Quality of Smoked Freshwater Fish Species Sold in Tamale Central Market, Northern Region, Ghana." Ethiopian Journal of Environmental Studies and Management 2 (2): 27-35.

Pearsall, D. M. 1980. "Pachamachay Ethnobotanical Report: Plant Utilization at a Hunting Base Camp." In Prehistoric Hunters of the High Andes, edited by J. W. Rick, 91-231. New York: Academic Press.

Pearsall, D. M. 2000. Paleoethnobotany: A Handbook of Procedures. San Diego: Academic Press.

Rostworowski, M. 1981. Recursos naturales renovables $y$ pesca, siglos XVI y XVII. Lima: Instituto de Estudios Peruanos.

Scheel-Ybert, R. 1998. "Stabilité de l'écosystème sur le littoral sud-est du Brésil à l'holocène supérieur (5500-1400 ans $\mathrm{BP})$ : les pêcheurs-cueilleurs-chasseurs et le milieu végétal: apports de l'anthracologie." $\mathrm{PhD}$ diss., Université Montpellier II.

Schweingruber, F. H. 2007. Wood Structure and Environment. Berlin: Springer.

Sillar, B. 2000. "Dung by Preference: The Choice of Fuel as an Example of how Andean Pottery Production is Embedded within Wider Technical, Social, and Economic Practices." Archaeometry 42 (1): 43-60.

Théry-Parisot, I. 2001. Économie des combustibles au paléolithique: expérimentation, taphonomie, anthracologie. Paris: CNRS.

Théry-Parisot, I., L. Chabal, and J. Chrzavzez. 2010. "Anthracology and Taphonomy, from Wood Gathering to Charcoal Analysis. A Review of the Taphonomic Processes Modifying Charcoal Assemblages, in Archaeological Contexts." Palaeogeography, Palaeoclimatology, Palaeoecology 291 (1-2): 142-153. 
Théry-Parisot, I., A. Dufraise, J. Chrzavzez, A. Henry, and S. Paradis. 2011. "Charcoal Analysis and Wood Diameter: Inductive and Deductive Methodological Approaches for the Study of Firewood Collecting Practices." Saguntum Extra 11: 31-32.
Weir, G. H., and P. Dering. 1986. "The Lomas of Paloma, Human-Environment Relationship in a Central Peruvian Fog Oasis: Archaeobotany and Palynology.” In Andean Archaeology, edited by R. Matos Mendieta, 1844. Los Angeles: UCLA. 